\title{
Korlederens kompetanse, utdanning og praksis - konturene av en meta-teori
}

\author{
Dag Jansson ${ }^{1}$ og Anne Haugland Balsnes ${ }^{2}$ \\ ${ }^{1}$ OsloMet - Storbyuniversitetet; ${ }^{2}$ Universitetet $i$ Agder
}

\begin{abstract}
Sammendrag
Korbevegelsen har et stort antall aktive medlemmer i Skandinavia. Alle de ulike korene som finnes - fra barnekor til seniorkor, fra hygge-kor til profesjonelle kor - trenger ledere. Korlederen må mestre et omfattende kompetansesett $\mathrm{i}$ det hun eller han virker som både musiker, leder og pedagog. Forfatterne har de siste årene gjennomført en rekke studier av korlederes utdanning og praksis, med ulike tilnærminger både når det gjelder forskningsmetode og materiale. På grunn av begrensningene i det klassiske vitenskapelige artikkelformatet har resultatene fra disse studiene så langt ikke blitt diskutert i sin helhet. I denne artikkelen tar vi et overordnet blikk og foretar en meta-analyse av de samlede resultatene. Artikkelen undersøker følgende spørsmål: Hvordan samvirker korlederutdannelse og -praksis i dirigenters kompetanseutvikling og konstituering av dirigentprofesjonen? Resultatene presenteres som en konseptuell modell som kombinerer tre perspektiver - læring i praksisfellesskap, tre stadier i en dirigentpraksis og en tredelt kompetansemodell for korledelse. Modellen blir diskutert i form av fem temaer; rekruttering til korlederyrket, betydningen av inngangsprofil, forholdet mellom utdanning og praksis, utfordringer i praksis og selvopplevd kompetanse samt mangfoldet i kordirigenters profesjonelle karrierer. Artikkelen peker på utfordringer i utformingen og implementeringen av korlederlederutdanning.
\end{abstract}

\section{Nøkkelord: Korledelse; dirigentkompetanser; korlederutdanning; praksisfellesskap}

Mottatt: Mai, 2020; Antatt: Oktober, 2020; Publisert: Dezember, 2020

\section{Abstract \\ The choral conductor's competence, education, and practice - an emerging meta-theory}

The choir movement involves a large number of active members in Scandinavia. All the various choirs - from children's choirs to senior citizen choirs, from leisure activity to professional choirs - need leaders. The choral leader needs to master a comprehensive set of skills in fulfilling the functions of musician, leader and teacher. The authors have over the recent years conducted a series of studies of choral leaders' education and professional practice, with a variety of approaches with regard to research method and data material. Given the limitations of the scholarly journal article format, these studies have not been, until now, discussed in its entirety. In the present article, we take an overview and conduct a meta-analysis of the previous results. The article investigates

^Korrespondanse: Dag Jansson, epost: dag.jansson@oslomet.no

(C) 2020 D. Jansson og A. H. Balsnes. This is an Open Access article distributed under the terms of the Creative Commons Attribution 4.0 International License (https://creativecommons.org/licenses/by-nc/4.0/), allowing third parties to copy and redistribute the material in any medium or format and to remix, transform, and build upon the material for any purpose, even commercially, provided the original work is properly cited and states its license.

Citation: D. Fansson $\&$ A. H. Balsnes. «Korlederens kompetanse, utdanning og praksis - konturene av en meta-teori». fournal for Research in Arts and Sports Education,Vol. 4(1), 2020, s. 92-114. http://dx.doi.org/10.23865/jased.v4.2354 
the following question: What is the interplay between choral conductor education and practice in building competence and the shaping of a choral conductor profession? The results are presented as a conceptual model that combines three perspectives - learning in communities of practice, three stages of a professional practice, and a three-layered model of choral conducting competencies. The model is discussed through five themes; recruitment into the choral leader profession, the significance of the entry platform, the relationship between education and practice, competencies in light of the challenges faced in working situations, and the great variety of choral leaders' professional trajectories. The article identifies issues for the design and implementation of choral leader education.

Keywords: Choral leadership; conducting competencies; choral conducting education; communities of practice

\section{Innledning}

Korbevegelsen har et stort antall aktive medlemmer i Skandinavia. Alle de ulike korene som finnes - fra barnekor til seniorkor, fra hygge-kor til profesjonelle kor trenger ledere. En korleder må besitte mange ulike kompetanser. Hun eller han er både musiker, leder og pedagog. Forfatterne har de senere årene vært involvert i en rekke studier som omhandler korlederkompetanse, -utdanning og praksis. Samlet representerer disse et stort og variert datagrunnlag som har vært analysert med ulike kvalitative så vel som kvantitative metoder. Så langt er de ulike resultatene ikke diskutert i sammenheng. Det klassiske artikkelformatet giør at man vanligvis tar for seg en problemstilling om gangen, og det er sjelden rom for å diskutere mer sammensatte problemstillinger. I denne artikkelen tar vi et overordnet blikk og forsøker å besvare følgende spørsmål: Hvordan samvirker korlederutdannelse og -praksis i dirigenters kompetanseutvikling og konstituering av dirigentprofesjonen? Artikkelen er en meta-analyse av resultatene fra de ulike studiene vi har publisert. En annen måte å beskrive tilnærmingen på er at vi teoretiserer de publiserte resultatene $i$ sammenheng. Materialet belyses av Wengers (1998) teori om læring i praksisfellesskap og Janssons (2018) kompetansemodell for korledelse. Formålet med artikkelen er å skissere en helhetlig teori for korlederes kompetanseutvikling og karriereforløp.

Begrepene kordirigent og korleder kan oppfattes med noe ulikt meningsinnhold (Jansson et al., 2018). Her anvendes begrepene imidlertid av praktiske grunner synonymt.

\section{Tidligere forskning}

Når forskningsfeltet er krysningen mellom korlederutdanning, -praksis og -kompetanse står vi ikke i noen entydig forskningstradisjon. Det er giennomført forskning i hver av de tre delområdene i varierende omfang og relevans - og innen ulike fagdisipliner. Utfordringen er å utnytte svært forskjelligartede bidrag til å forstå samspillet mellom de tre områdene, hvilket også er motivasjonen for denne artikkelen.

Forskning på korledelse hører delvis hjemme i det videre feltet korforskning. Den samlede korforskning over de siste hundre år utgjør omkring 5000 publikasjoner 
(Geisler, 2010). Bredden i temaer er stor, og det finnes en gråsone mot halvakademiske lærebøker. Det finnes også endel forskning på orkesterdireksjon som har relevans for korledelse, både når det gjelder ledelse og gestiske aspekter (Atik, 1994; Biasutti, 2013; Cofer, 1998; Faulkner, 1973; Gilling, 2014; Stambaugh, 2016; Woodbury, 1955). Forskning på spesifikt korledelse omfatter tre tilgrensende og delvis overlappende tradisjoner - (1) korlederkompetanse og -pedagogikk, (2) korlederutdanning og (3) korledelse som sosial praksis og profesjon. Vi har valgt denne strukturen for den påfølgende gjennomgang, selv om innplasseringen ikke alltid er entydig.

\section{Korlederkompetanse og -pedagogikk}

Det finnes en mengde bøker om kordireksjon fra det siste århundret, skrevet av dirigenter og for det meste basert på deres egen praksis og nært knyttet til konkret musikalsk anvendelse (Adler, 1985). Den største delen av forskningen, særlig i USA, har en pedagogisk innretning. Tidligere oversiktsartikler konstaterte at dirigentforskning i hovedsak ble utført av dirigenter i gjennomføringen av et doktorgradsarbeid. Forskningen bar dermed preg av engangsinnsatser av blandet kvalitet uten systematisk kompetanseoppbygging (Gonzo, 1973; Grant \& Norris, 1998; Hylton, 1983, 1998). Denne tradisjonen synes å vedvare, selv om det samlede kunnskapsgrunnlaget forsterkes gradvis over tid, for eksempel når det gjelder gestikk og pedagogikk.

Forskning på gestikk - dirigentens bevegelser - handler dels om å forstå underliggende virkningsmekanismer, særlig det som er knyttet til synkronisering av ensemblet (Burger et al., 2014; Luck \& Nte, 2008; Luck \& Sloboda, 2008; Luck \& Toiviainen, 2006). Andre er opptatt av gestikkens ekspressive funksjon (Byo, 1990; Morrison et al., 2014), hvordan gestikken kan understøtte sangernes vokalteknikk (Fuelberth, 2003), eller hvilket kroppsaspekt som virker - hender, blikk og kroppsholdning (Silvey, 2013; Van Weelden, 2002; Wöllner, 2008). Alan Gumm (2018) har undersøkt gestikkens ulike funksjoner og hvordan disse samspiller i dirigentens musikalske ledelse.

Den andre store pedagogiske hovedkategorien handler om korøvelsen, som i amerikansk tradisjon behandles som en undervisningssituasjon der dirigenten er lærer og sangeren elev (Yarbrough \& Madsen, 1998). Forskningen handler blant annet om struktur og opplegg for øvelsen (Cox, 1989; Brunner, 1996; Durrant, 2000), så vel som kommunikasjon i øvesituasjonen, for eksempel feedback og signaler til sangerne (Bonshor, 2017; Yarbrough, 1975), språkbruk (Black, 2014), feilretting (Crowe, 1996) og balansen mellom verbale og gestiske signaler (Bygdéus, 2015; Napoles, 2013, 2014; Sandberg-Jurström, 2009; Skadsem, 1997).

Et tredje blikk rettes mot selve dirigentrollen, hvor én tilnærming er spesifikke aspekter, for eksempel forholdet mellom makt og bemyndigelse (Guise, 2001; Patman, 1987), spenningsforholdet mellom kunstner og pedagog (Freer, 2011) og betydningen av kjønn og rase (Apfelstadt, 2009; Van Weelden \& McGee, 2007). 
En mer generell variant er å anvende klassiske ledelsesteorier på kordirigentrollen (Armstrong \& Armstrong, 1996; Wis, 2002). Noen forskere har forsøkt å etablere overordnede modeller for hvordan enkeltheter i rollen kommer sammen til en helhet (Butt, 2010; Durrant, 1994, 2003; Garnett, 2009; Gumm, 2012, 2018; Jansson, 2013, 2018).

To av våre studier har forsøkt å bygge bro mellom rollens enkeltheter og det helhetlige blikket. Tilnærmingen har vært å analysere den relative betydningen av ulike kompetanse-elementer og dirigenters selvopplevde mestring av disse (Jansson et al., 2019a, 2019b). Et sentralt funn, og et av utgangspunktene for denne artikkelen, er at det i noen grad er et misforhold mellom dirigentenes kompetansevurdering og innholdet i utdanningene, og at praksis ofte overskygger utdanning.

\section{Korlederutdanning}

Varvarigou \& Durrant (2011) har foreslått et rammeverk for å diskutere læringsopplegg for korledere. Det korresponderer med etablerte didaktiske kategorier (Bjørndal \& Lieberg, 1978; Hanken \& Johansen, 2013), men er tilpasset til korledelse. Tilpasningen innebærer en detaljering av to forhold - kortype/repertoar og læringsutbytter. Når det gjelder læringsutbytte, inkluderer rammeverket Durrants (2003) kompetanse-inndeling i musikalsk-tekniske, mellommenneskelige og filosofiske prinsipper. Læringsprosesser for korledere er i liten grad forsket på, selv om Durrant \& Varvarigou (2008) også har interessert seg for korlederes utvikling. Vallo (1990) foretok en gjennomgang av ulike tilnærming til dirigentutdanning, som på grunn av begrenset materiale de facto gjaldt musikkutdanning i videre forstand. Han skilte mellom fem ulike tilnærminger, som i Varvarigou og Durrants rammeverk dekker "prosess»: adferdsbasert, kompetansebasert, erfaringsbasert, sosialpsykologisk og akademisk. Han konkluderte med at vi har svært liten kunnskap om hvilke tilnærminger som fungerer best.

Når det gjelder forskning på korlederutdanning, var en av våre studier kartlegging av akademiske dirigentutdanninger i Skandinavia, hvor formålet var å etablere et første bilde av institusjoner, profiler/innhold og kapasitet (Jansson et al., 2018).

\section{Korledelse som sosial praksis og profesjon}

Korledelse som profesjon har i liten grad vært studert. Dette må antas å skyldes at faget i stor grad har vært innbakt i andre profesjoner, som lærer og kirkemusiker. Det finnes en tradisjon for å studere kor som sosial praksis, hvilket utgjør konteksten for dirigentpraksis (Eiksund, 2019; Geisler \& Johansson, 2014; Jansson, 2013, 2018). Det finnes enkelte eksempler på studier av eksplisitt betydning av korlederens kontekst, herunder rase, kultur og sjanger (Van Weelden \& McGee, 2007; Yoo, 2017). Det finnes også en viss tradisjon for å betrakte kordirigentpraksis gjennom framstående dirigenters fortellinger (Blocker, 2004; Fowler \& Swan, 1987; Johansson, 2015). En konsekvens av manglende kunnskap om korlederes praksis, er at vi vet lite 
om forholdet mellom utdanning og praksis. En av våre studier forsøkte å belyse dette forholdet gjennom å teoretisere det store mangfoldet av kordirigenters utviklingsbaner, fra første eksponering for faget, via utdanning til en livslang praksis (Jansson \& Balsnes, 2020). Ser vi den samlede korforskning under ett, framstår den som spredt og fragmentert. Det er derfor behov for forskning som i større grad ser sammenhenger og forbinder korlederrollens enkeltheter med helheten, hvilket er hensikten med denne studien.

\section{Studiens teoretiske perspektiver}

Musikalsk ledelse er blitt teoretisert som mestring på ulike nivåer, med litt varierende konseptualiseringer. En gjennomgripende taksonomi i generell ledelsesteori skiller mellom tekniske, mellommenneskelige og konseptuelle kompetanser (Campion et al., 1994, 2011). Ladkins (2008) taksonomi, som tar for seg musikalsk ledelse i vid forstand, omfatter mestring (teknikk og situasjon), kongruens (mellom alle tilstedeværende elementer) og meningsfylthet. Spesielt for korledelse, skiller Durrant (2003) mellom musikktekniske ferdigheter, mellommenneskelige ferdigheter og filosofisk fundament. Janssons (2018) modell, som bygger på korsangeres opplevelse av musikalsk lederskap, utvider Durrants mellommenneskelige kategori ved å inkludere situasjonell mestring. Likeledes spiller mestring av mellommenneskelige relasjoner alltid ut i konkrete situasjoner. Jansson argumenterer også for en bredere tredje kategori, som i tillegg til filosofiske prinsipper og formål også inkluderer grunnleggende trekk som tilstedeværelse, autoritet, vilje, hengivenhet og oppriktighet - til sammen betegnet som eksistensielt fundament. Det er et sentralt poeng at dette fundamentet alltid er kroppsliggjort i en ledelsespraksis (Bathurst \& Cain, 2013; Fisher \& Robbins, 2015; Ladkin \& Taylor, 2010) og ikke kan reduseres til verbaliserte prinsipper. De tre modifiserte kategoriene som Jansson (2018) etablerte til å beskrive dirigentkompetanse er derfor de samme som vi legger til grunn i denne studien:

(1) musikalsk-teknisk mestring

(2) situasjons-relasjons mestring

(3) eksistensielt grunnlag

Musikalsk-teknisk mestring omfatter forskjellige fagområder som ofte finnes i fagplaner i høyere musikkutdanning: repertoarkunnskap, notelesingsferdigheter, ferdigheter innen gehør, gestikk-ferdigheter, vokalteknikk, språkkunnskaper og korakustikk. Noen av disse hører spesielt til dirigentrollen, mens andre er generiske musikkompetanser og til og med utenom-musikalske kompetanser. Felles for dem alle er at de kan læres (i det minste til en viss grad) utenfor ensemblesituasjonen.

Situasjons-relasjonskompetanse får sin mening i det konkrete møtet med korsangere. To store kategorier er knyttet til innstudering - organisering av innstuderingsprosessen og spesifikke intervensjoner i øvesituasjonen. Valg av intervensjon skjer 
kontinuerlig, og dirigenten har en mengde teknikker til disposisjon - noen spredte eksempler er feilretting, vokal demonstrasion, pianospill, gjentagende gjennomsynging, verbal forklaring, bruk av YouTube-filer, ulik kombinasjon av stemmegruppene, synge uten tekst og eksperimentere med ulike tempi. Utnyttelse av rommet og plassering av sangerne er en distinkt kompetanse som både krever akustikkinnsikt og menneskekunnskap. Siden dirigenten i øvesituasjonen kontinuerlig gir tilbakemelding, er veiledning/mentorskap en nøkkelkompetanse. Den betinger både god situasjonsbedømmelse og innsikt i sangernes forutsetninger. Disse ulike situasjonsrelasjons-kompetansene kommer til sammen i et hele som spiller seg ut som en balanse mellom kontroll og bemyndigelse av sangerne. Dirigenter kan både giøre for mye og for lite $-\mathrm{i}$ øvesituasjonen såvel som i konsertsituasjonen. Evnen til å bedømme dette godt er øyeblikkskunst, siden hva som er riktig inngrep hele tiden endrer seg giennom innstuderingsprosessen (makro-nivå) så vel som i den musikalske flyten (mikro-nivå).

Det eksistensielle grunnlaget omfatter elementer som i ledelsesteori sjelden defineres eksplisitt som kompetanser. Visse aspekter er isteden konseptualisert som distinkte lederstiler, for eksempel autentisk ledelse (Bass \& Steidlmeier, 1999; Gardner et al., 2011; Ladkin \& Taylor, 2010) og tjenende lederskap, som legger vekt på altruisme og hengivenhet til ensemblet (Beck et al., 2014; Wis, 2002). For dirigentrollen, imidlertid, viser studier at disse trekkene er helt avgiørende og til dels viktigere enn de tekniske og mellommenneskelige ferdighetene (Jansson, 2019; Jansson et al., 2019a). For dirigentrollen kan de ikke reduseres til en stil, de er alltid nærværende forutsetninger og må derfor betraktes som en grunnkompetanse. Det eksistensielle grunnlaget handler delvis om hvilken kraft dirigenten kommer inn i ensemble-situasjonen med, representert ved autoritet og musikalsk vilje. Uten disse faller rollens legitimitet bort. Videre handler det om hva slags forpliktelse dirigenten møter ensemblet med, representert ved tilstedeværelse, hengivenhet og oppriktighet.

I tillegg til kompetansemodellen er Etienne Wengers konsept laring $i$ praksisfellesskap (1998) valgt for å belyse materialet. Hans læringsteori, som er basert på praksis og læringsbaner, egner seg godt til å studere læring som foregår over en lengre periode - som i vårt tilfelle er korlederes livslange læring/utvikling. Et praksisfellesskap refererer til den sosiale læring som finner sted når en gruppe mennesker over tid samarbeider om en felles interesse. Læring er en nøkkelfaktor i sosiale praksiser og finner sted gjennom deltakelse. Læring er en generativ prosess - den giør noe med oss, den transformerer hvem vi er og hva vi er i stand til å gjøre. Som en konsekvens av dette vil også selve praksisfellesskapet være i konstant endring. Meningen med en praksis forhandles kontinuerlig av de individuelle erfaringene som giøres og endrer i sin tur også praksis. Alle mennesker deltar i mange forskjellige mer eller mindre overlappende praksisfellesskap med ulike medlemmer. I vårt tilfelle danner de ulike korene våre informanter deltar i tilgrensende praksisfellesskap. På utdanningene deltar studentene i flere forskjellige praksisfelleskap, og man kan også betrakte kollegiet av dirigenter som et stort praksisfellesskap. I vår analyse anvender vi følgende av 
Wengers kategorier: Kompetanse - læring som mestring; fellesskap - læring som tilhørighet; mening - læring som erfaring; identitet - læring som tilblivelse.

Vi har valgt læring i praksisfellesskap som hovedteori for å undersøke kordirigenters læringsprosesser, og kompetansemodellen som hovedteori for å undersøke læringsinnholdet. I diskusjonsdelen peker vi på enkelte berøringspunkter med andre teorier, blant annet teori om mestringstro (Bandura, 1977; Hannah et al., 2008) og teori om meningsdannelse (sensemaking). Sensemaking-teori ble utviklet for å ta høyde for at mennesker opererer i omgivelser og organisasjoner som er preget av kompleksitet, uperfekt informasjon, uforutsigbarhet og flertydighet (Humphreys et al., 2012; Weick, 1995, 1998). Et nøkkelpoeng er at mennesker skaper mening ved å handle på en måte som er plausibel, det vil si, god nok til å komme videre. Behovet for ny mening utløses tydeligst når ny erfaring er i konflikt med etablerte oppfatninger. Slik kognitiv dissonans (Festinger, 1957; Hinojosa et al., 2017) oppstår når dirigenter møter kompetansegap, for eksempel ikke får en jobb de søker på eller erfarer et de kommer til kort på en teknisk eller relasjonell ferdighet (Jansson \& Balsnes, 2020). I en dirigents utviklingsprosess er individets identitet en ramme, samtidig som den kan måtte endres for å redusere dissonansen.

\section{Metode og materiale}

\section{Underliggende studier}

I denne delen presenterer vi kort de underliggende studiene. Dette gjøres summarisk $i$ tabell 1. For detaljer henvises til de enkelte publikasjonene.

Både korsangere og dirigenter er kilder til å forstå dirigentrollen, og vi dekket et stort spenn av dirigentsituasjoner og kortyper (profesjonelle kor, kammerkor, kirkekor, lokalt blandakor, gospelkor, seniorkor, sang på jobben-kor). Vi har intervjuet til sammen 54 sangere individuelt, og foretatt fokusgruppeintervjuer med to ulike grupper kordeltakere. Vi har videre intervjuet åtte dirigentlærere og 34 dirigenter (tolv av dem nyutdannede). 684 norske, svenske og tyske dirigenter har deltatt i spørreundersøkelser og ulike kor-relaterte dokumenter er analysert. Metodetilfanget giør at vi har fått et bredt sammensatt og nyansert materiale som vi tidligere ikke har hatt i Skandinavia. Studiene gir innsikt i korsangeres opplevelser og tanker om dirigenter, samt kordirigenters egne refleksjoner omkring rollen, kompetanse og hvordan utdanning og erfaring samspiller.

\section{Den foreliggende studien}

Studiene som inngår er basert både på kvalitative og kvantitative metoder. Imidlertid giør vi i denne artikkelen bruk av kvalitative innsikter fra de kvantitative studiene. Vi må derfor karakterisere vår metode her som utelukkende kvalitativ. Siden vi går inn $i$ analysen med allerede etablerte forestillinger om fenomenet vi undersøker, er vår tilnærming en abduktiv logikk som innebærer en dialog mellom eksisterende kunnskap og nye forestillinger om fenomenet vi undersøker (Rennie, 2012; Timmermans 


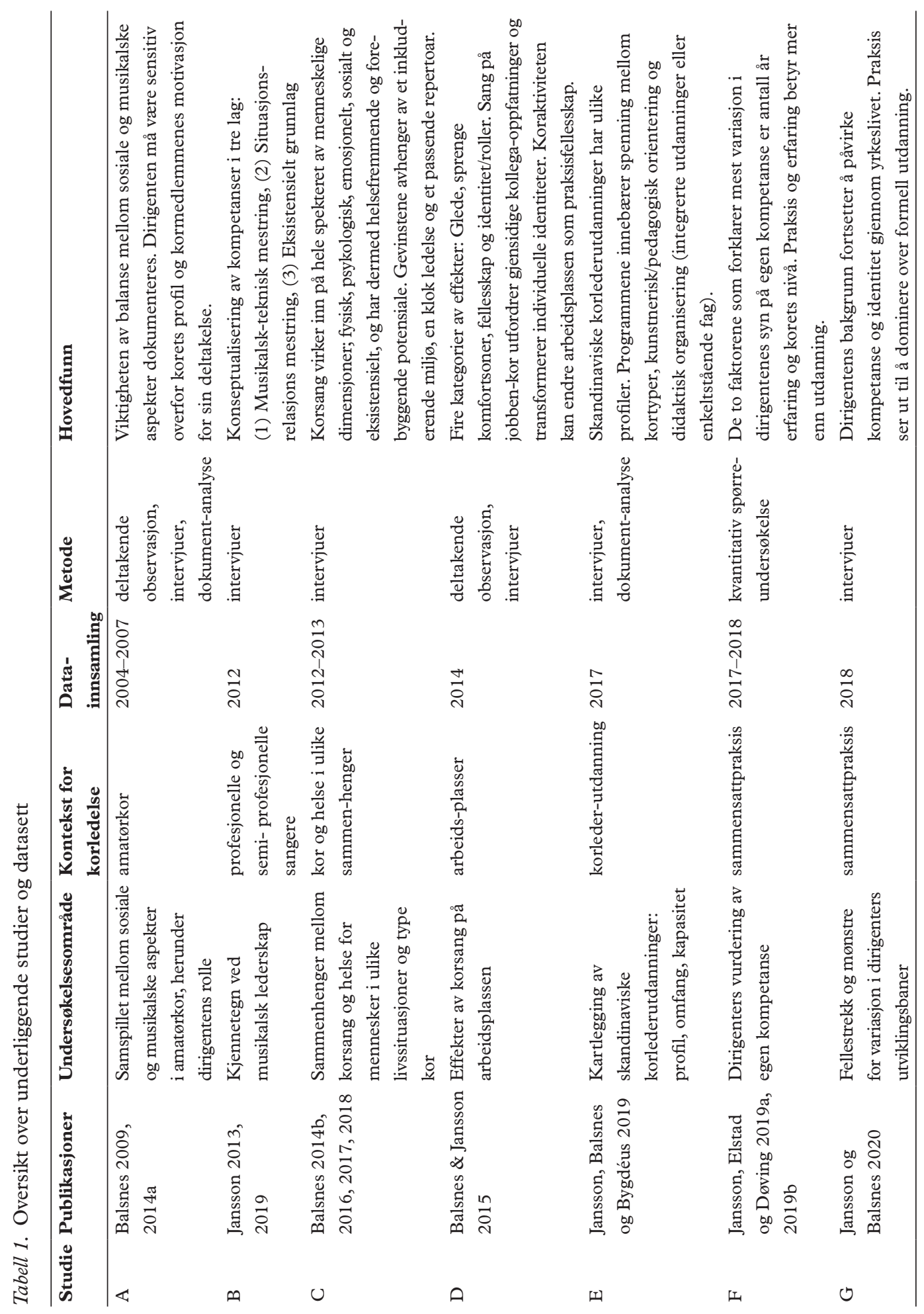


\& Tavory, 2012). Vi baserer oss på en praksis-orientert abduktiv metode som både gir rom for logikk og intuisjon, og forforståelse så vel som tilsidesettelse av antagelser (bracketing) (Raelin, 2020). Abduktiv metode er mer egnet til å utvikle teori enn å teste teori, hvilket korresponderer med artikkelens innretning.

Forskningsspørsmålet om hvordan korlederutdannelse og -praksis samvirker i dirigenters kompetanseutvikling og konstituering av dirigentprofesjonen innebærer dels en sammenstilling av ulike resultater og dels en konseptualisering, det vil si teoribygging. Det sentrale ordet i forskningsspørsmålet er samvirke - hvordan korlederutdannelse og -praksis samvirker i dirigenters kompetanse- og profesjonsutvikling. Teoribyggingen foregikk som en iterativ prosess mellom foreløpige konseptuelle idéer og videreutvikling av disse ved å bringe inn ytterlige data og ta et fornyet blikk på idéene.

Analysen ble gjennomført som to parallelle prosesser - en logisk-deduktiv (A) og en kreativ-induktiv (B). Det foregikk dermed en dialog mellom oppdatert innsikt og idéer til ytterligere forbedringer. De to prosessene og interaksjonen mellom dem er forenklet illustrert i figur 1.

(A) Logisk-systematisk prosess for å identifisere og verifisere enkeltfenomener. Denne søkte å sikre at resultatet er uttømmende gitt de underliggende studiene, det vil si orientert mot å ivareta reliabilitet. De konkrete trinnene var:

(A1) Vi tok utgangspunkt i G-studien, fordi denne tydeligst hadde et livsløpsblikk på korlederen giennom de tre fasene utgangsplattform, utdannelse og praksis. Vi gjennomgikk de øvrige studiene for å vurdere elementer i livsløpet som studiene berørte.

(A2) Vi tok videre utgangspunkt i studiene som omhandler situert læring (A-, C-, D- og G-studien) for å sikre en mest mulig rikholdig forståelse av hver av de fire dimensjonene felleskap, identitet, mening og kompetanse.

(A3) Vi rettet så oppmerksomheten spesifikt mot kompetanse-begrepet, som særlig er omhandlet i B-, E- og F-studiene. Vi undersøkte spesielt livsløpsaspekter for de tre kompetansekategoriene (jf. s. 5). I løpet av denne prosessen identifiserte og systematiserte vi de ulike elementer i de underliggende studiene. Den kreativ-utforskende prosessen på sin side søkte å utvikle en struktur på disse elementene:

(B) Kreativ-utforskende prosess for å konseptualisere helheten og sammenhenger. Denne tok sikte på å ivareta validitet, det vil si at resultatet faktisk avspeiler helheten.Vi fortolket dette som kompletthet $i$ kombinasjon med enkelhet når det gjelder omfanget av sammenhenger. De konkrete trinnene var:

(B1) Vi undersøkte om de identifiserte elementene var distinkte, det vil si at de verken var overlappende eller delmengder av hverandre.

(B2) Vi undersøkte sammenhenger mellom de ulike elementene og alternative måter å konseptualisere disse på. 
(B3) Vi undersøkte ulike måter å sammenstille alle elementer og sammenhenger. Reliabilitet og validitet innebærer her at funnene fra de underliggende studiene er representert, samtidig som det verken er manglende eller overflødige sammenhenger.
A: LOGISK-SYSTEMATISK PROSESS
B: KREATIV-UTFORSKENDE PROSESS

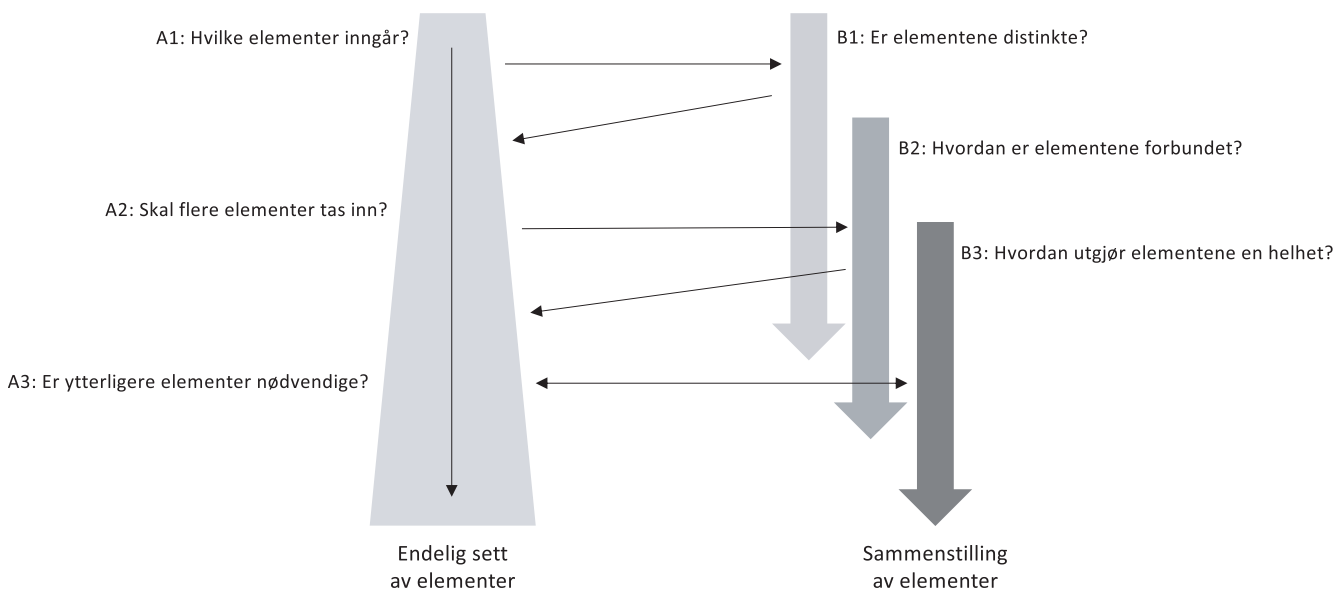

Figur 1. Forenklet illustrasjon av analyseprosessen

I gjennomføringen av meta-analysen framkom ulike temaer, spørsmål og dilemmaer. I tillegg til å være del av den foreslåtte konseptualiseringen, betrakter vi også disse som et direkte resultat av analysen. De tilfører nye perspektiver utover hva de tidligere studiene hadde frambragt.

\section{Resultater}

Temaene fra de underliggende studiene er konseptualisert i figur 2. Modellen inneholder tre hovedperspektiver som er satt i sammenheng: (1) Den fremstiller kompetanseutvikling innenfor dirigenters karriereforløp som et vedvarende livslangt prosjekt fra start-plattform, via utdannelse til arbeidslivspraksis. (2) Gjennom dette løpet foregår det et samspill mellom elementene i modellen for situert læring i praksisfellesskap. (3) Kompetanse-elementet er detaljert i form av tre-lags-modellen for dirigentkompetanser.

De ulike fasene i en kordirigents yrkeskarriere forløper ikke alltid strengt i denne rekkefølgen, for eksempel hvis utdannelsen tas etter en tids praksis. Mange dirigerer også kor ved siden av studiene. Hvis dirigentutdannelsen er i form av emner $i$ et annet program, kan dette også være selve startpunktet. Første eksponering for kordirigering er et viktig, men ofte glemt aspekt av karriereutviklingen (studie G, 


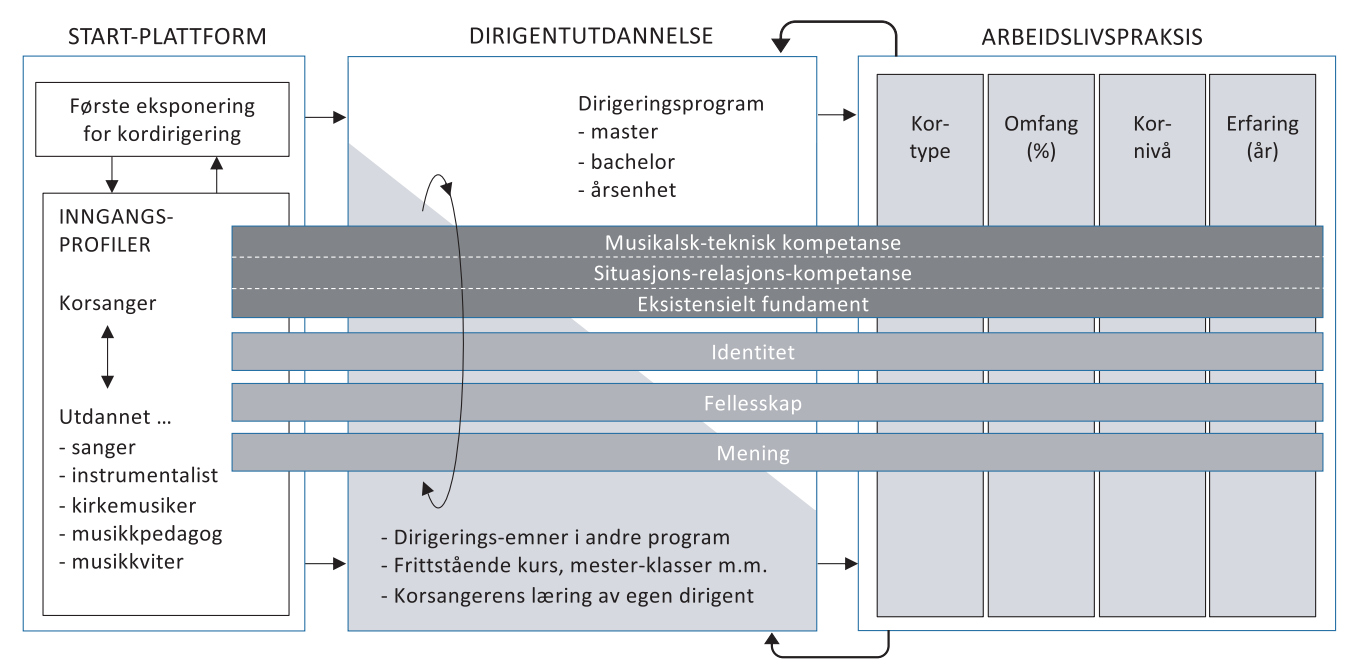

Figur 2. Modell for utvikling av dirigentpraksis og -kompetanse

jf. tabell 1). Det er et nøkkelpunkt for den enkelte, og antallet som blir eksponert er avgjørende for rekruttering til profesjonen. De ulike inngangsprofilene definerer et kompetansegrunnlag, men preger også identitet langt ut i yrkesforløpet. En dirigents arbeidsliv kan selvsagt ikke fanges opp fullstendig av de fire variablene som er vist i modellen (kortype/nivå, dirigentjobbenes omfang i prosent og antall års erfaring som kordirigent).Vi mener likevel de er nøkkelfaktorer som spiller inn på dirigentens kompetanseutvikling.

Tre av de fire kategoriene i situert læring er avbildet gjennomgående i hele forløpet: identitet, felleskap og mening. Den fjerde kategorien - kompetanse - er avbildet $\mathrm{i}$ form av sine tre kompetanselag. Hele dirigentens yrkesforløp innebærer kompetanseutvikling samtidig som det er identitetsformende. Kompetanse og identitet kan betraktes som én retning: levd liv leves bare framover. Fellesskap og mening er derimot faktorer som ligger under og fluktuerer - felleskapene skifter, og praksis kan både bli mer eller mindre meningsfylt over tid.

De tre kompetanselagene er også avbildet gjennomgående i hele forløpet. Dette betyr ikke nødvendigvis at de tre lagene utvikles med samme intensitet giennom forløpet. Individuell «progresjon» kan oppvise store variasjoner, og hendelser og situasjoner kan forandre forløpet.

Enkeltelementer innenfor denne helhetlige rammen (som for eksempel utdannelsesnivå og identitet) er diskutert i de underliggende studiene. Det som er nytt av resultater er perspektivet på elementene, sammenhengen mellom dem og ikke minst at disse kan diskuteres med et mer sammensatt og rikholdig datagrunnlag enn tidligere. Gjennom meta-analysen identifiserte vi fem hovedtemaer som i helhetsperspektivet framtrer særlig betydningsfulle og som vi velger å strukturere den påfølgende diskusjon etter: 
(1) Rekruttering til dirigentutdannelse og dirigentyrket

(2) Betydningen av dirigentenes inngangsprofil for yrkesforløpet

(3) Forholdet mellom utdannelse og praksis

(4) Utfordringer i praksis og selvopplevd kompetanse

(5) Mangfold i dirigentenes profesjonelle livsløp

Når det i den følgende diskusjonen henvises til studie A, B, og så videre, gir tabell 1 informasjon om hva som inngår i de ulike studiene.

\section{Diskusjon}

Rekruttering til dirigentutdannelse og dirigentyrket

Det finnes flere innganger til dirigentyrket, men uansett bakgrunn finnes det alltid en første eksponering for dirigering. Så godt som alle kordirigenter har selv sunget i kor i oppveksten (studie G). Mange nevner dirigentforbilder de har hatt som en av årsakene til at de selv ble dirigenter. Flere forteller om nærmest tilfeldige muligheter til å prøve seg foran et kor, og hvordan de dermed fikk en første smak på rollen. Det kan ha vært en situasjon hvor den faste dirigenten var fraværende, en lærer som tipset en student om en ledig dirigentjobb eller en musikkstudent på jakt etter jobb ved siden av studiene. Mange får en smakebit på dirigering gjennom direksjonskurs på videregående eller i musikkutdanning. Møtet med en engasjert lærer kan også være starten på en dirigentkarriere.

Disse ulike inngangene illustrerer lave terskler til praksisfellesskapet, hvor perifer deltakelse ikke bare er legitim, men avgjørende for det videre forløpet (Lave \& Wenger, 1991). Barne- og ungdomskor er dermed viktige arenaer. Tilhørighet i slike fellesskap gir utviklingsmuligheter over tid. Men unge sangere må også eksponeres for opplevelsen av å lede koret. En større systematikk i å la unge korsangere få prøve seg som dirigenter kan bety at flere oppdager «det berusende, magiske og ærefulle i å stå foran og alle regner med deg," slik en nyutdannet dirigent formulerer det $\mathrm{i}$ intervju (studie E). De to elementene fellesskap og mening synes i denne fasen vel så viktig som kompetanseelementet. Både erfarne og nyutdannede dirigentene fremhever ulike dimensjoner ved det meningsfulle de opplever gjennom å lede kor, det fysiske ved å dirigere - å nærmest kunne ta på musikken, det sosiale ved korsang (som man ikke har som solist eller pianist), å få folk til å blomstre, å skape musikkglede og bidra til menneskers mestringsopplevelser (studie E). En annen dimensjon ved mening er noe så praktisk som økonomi. Å tjene penger er i flere tilfeller hovedårsak til at noen velger å bli dirigenter (studie G). Særlig for musikere som har smale karrierer kan det å lede kor gjøre en frilanstilværelse mulig. Noen oppdager at de liker å lede, og «finner seg selv» gjennom å stå foran kor. Andre finner at dirigentrollen kompletterer sin profil, som den sangutdannede dirigenten som følte seg for «bred» til kun å være klassisk sanger og opplevde at ting falt på plass da hun prøvde seg som dirigent. Her er det fjerde elementet i situert læring i spill - identitet. I sum ser vi at 
rekrutteringssituasjonen er like mangefasettert som praksis, hvilket ikke er tilsvarende reflektert i utdanningene.

\section{Betydningen av dirigentenes inngangsprofil for yrkesforløpet}

Det finnes knapt noen vei inn i kordirigentyrket som ikke går veien via å være korsanger. For noen er dette eneste plattform for en korlederpraksis. $26 \%$ av dirigentene i spørreundersøkelsen har ingen musikkutdanning (studie F). Flertallet har imidlertid musikkutdanning, og vi identifiserte seks utgangspunkter basert på type musikkutdanning: musikkvitenskap, musikkpedagog, musikkterapeut, kirkemusiker, instrumentalist og sanger. Blant disse har en del rene dirigentutdanninger eller musikkutdanning med hovedfokus på kor som gir en akademisk grad - bachelor, master eller hovedfag i korledelse - men av hele populasjonen utgjør disse bare $36 \%$. Det finnes få slike utdannelser, og det tas inn et lite antall studenter på hvert kull. Tallene innebærer en viss definisjonsmessig usikkerhet, siden respondenter kan fortolke en musikkutdanning med fokus på korledelse som en grad i korledelse. Den vanligste utdanningsprofilen er nettopp denne: dirigering inngår i musikkstudiet - som på kirkemusikk eller musikkpedagogikk - eller man tar en årsenhet $\mathrm{i}$ dirigering $\mathrm{i}$ ettertid. Dirigenter som har hatt en utøvende musikkutdanning som inngangsprofil, vil gjerne først og fremst se på seg selv som musikere - som også driver med korledelse - for eksempel denne sangeren som uttaler følgende i intervju: «Min primære identitet er fortsatt sanger, men uttrykksform nå de siste årene, har vært kordirigering." (studie F). Selv de som på et eller annet tidspunkt gjør en tydelig identitetsforandring fortsetter å bygge på sin grunnkompetanse.

Kordirigenter synes å være svært bevisst sine styrker og svakheter og tilpasser seg disse. De bruker de ferdighetene de har, og kompenserer for det de mangler. En korleder som er pianist vil naturlig bruke sin styrke i partiturspill, mens en sanger naturlig vil foresynge - slik denne sangerdirigenten uttaler: «Det at jeg synger er et av elementene for å lykkes i kordireksjonsverden.» (studie G). En korleder med et rikholdig gestisk repertoar vil være mindre avhengig av verbal instruksjon. Kordirigenter med korps- eller orkesterbakgrunn har gjerne innarbeidet en ryddig slagteknikk, men kan oppleve korledelse som en annen måte å vifte på (studie G).

Inngangsprofilen til dirigentyrket preger praksis i betydelig grad. En profil representerer et reservoar av ferdigheter som kan tas i bruk og som kombineres i formingen av en karriere. Den viktigste implikasjonen er påminnelsen om at kordirigenten først og fremst er medmusiker - med noen dedikerte oppgaver og tilleggsferdigheter.

\section{Forholdet mellom utdannelse og praksis}

Våre studier kaster lys på forholdet mellom utdanningene som finnes og hvilke kompetansebehov dirigenter har i praksis. På sitt beste kan utdannelse være strukturert, systematisk og omfattende og tilby en verktøykasse av stor verdi for det videre 
yrkeslivet (studie $\mathrm{E}$ og G). Mange av dirigentene forteller at de opplevde å utvikle seg både musikalsk og personlig gjennom studiet, ikke minst på grunn av praksisfellesskapet utdanningen representerte, hvor både medstudenter og lærere inngår (studie G). Resultater viser at dirigentutdannelse bidrar signifikant til nåværende kompetansenivå, men ikke musikkutdannelse generelt (studie F). Dette tyder på at dirigentutdannelse ikke bare handler om ferdigheter i snever forstand, men også om trygghet i rollen, den gir en laugsidentitet - en kombinasjon av Wengers (1998) kategorier identitet og tilhørighet.

Utdanningen kan også oppleves som direkte ødeleggende. I vårt materiale har vi dirigenter som forteller at de har fått overdose av krevende lærere eller opplevde undervisningen som en tvangstrøye - utdannelsen har dermed kommet på kollisjonskurs med selve meningsdimensionen for de aktuelle studentene (studie G). Slike hendelser kan teoretiseres som kognitiv dissonans (Coutinho, 2010; Festinger, 1957; Hinojosa et al., 2017). Individet tvinges til resolutt håndtering, i form av konkret handling, refortolkning av situasjonen eller endret selvforståelse. Det ser også ut til å være en dikotomi mellom det standardiserte og det personlige ved direksjon som flere strever med - og denne spenningen er i liten grad problematisert $\mathrm{i}$ dirigentutdanningene.

Utdanningene dekker best opplæring innen musikalske-tekniske kompetanser (studie E). Blant de ulike tekniske kompetansene skiller hørelære skiller seg ut ved at jo lenger praksis man har, desto mer setter man pris på utdannelsens bidrag og innser hvor vanskelig det er å lære basis på et senere tidspunkt om man ikke har et godt skolegrunnlag (studie F). Når det gjelder gestiske ferdigheter, er det i noen grad motsatt. Skoleringen trer i bakgrunnen jo mer praksis man har. Det samme gjelder innstuderingskompetanse. Gestikk er det element som rangerer høyest når det gjelder utdannelses bidrag til nåværende kompetanse - for mange er nettopp dette det eneste de lærte.

Situasjons-relasjonelle kompetanser er mer utfordrende å undervise. Det er mange eksempler i vårt materiale på dirigenter som uttrykker at de «møter en helt annen virkelighet» når de kommer ut i praksis (studie $\mathrm{A}$ og E). Særlig etterlyses opplæring i mellommenneskelige ferdigheter og eksponering for ulike kortyper (studie G). «Utdanningen tilbyr profesjonelle sangere [i øvesituasjonen] som kan alt, det kan ikke korene du kommer til,» sier en av informantene i utdanningsstudien (studie E). I utdanningen handler dette mye om ressurser til øvingskor, hva slags øvingskor man får prøvd seg på (ofte medstudenter og innleide sangere) og hvor mye praksis det er i løpet av studiet. Det eksistensielle grunnlaget (nivå tre i kompetansemodellen) er avhengig av modning og utvikles gjennom et livsløp mer enn det kan læres i løpet av et kort studium.

En stor andel kordirigenter deltar på kurs og masterclasses i regi av kororganisasjonene (studie G). Dette gir også rom for kurs med mer spisset tematikk. Dirigenten, som opprinnelig er instrumentalist, kan følge kurs i vokalteknikk, og sangeren kan lære mer slagteknikk. Imidlertid viser kursdeltakelse ingen signifikant effekt på 
selvopplevd kompetanse (studie F). Det mest fremtredende resultatet er at praksis trumfer utdanning. "Jeg har lært det aller meste gjennom praksis", er et gjennomgående utsagn (studie G). Dette utsagn resonnerer med synet på læring som en vedvarende og deltakende praksis (Lave, 2012; Lave \& Wenger, 1991; Wenger, 1998). I mange tilfeller er det en glidende overgang mellom utdanning og praksis. Dirigentstudenter har ofte dirigert kor både før og under studietiden. Praksis gir mengdetrening og fordypning. Situasjonsbedømmelse må læres i hvert enkelt tilfelle - ingen kor er like. Å være dirigent er dermed et livslangt prosjekt. Praksis er på mange måter en eneste lang videreutdanning. For det meste handler praksis om å dirigere egne kor, men også erfaring som korist er verdifull: "Alle de som blir dirigenter har sunget i kor", sier en av dirigentene vi har intervjuet (studie G). Dirigenter videreutdanner seg ved å ta kurs arrangert av kororganisasjonene, eller legger opp til egen utvikling ved å synge i kor med anerkjente dirigenter, observere dirigenter på konserter eller gjennomføre samarbeidsprosjekter med andre kor og dirigenter. Å bevege seg mellom ulike tilgrensende korpraksisfellesskap er dermed en nøkkel til den profesjonelle utviklingen, ikke bare når det gjelder kompetanse, men også tilhørighet og identitet (Arthur, 2016; Gherardi et al., 2000; Handley et al., 2006; Oborn \& Dawson, 2010).

\section{Utfordringer i praksis og selvopplevd kompetanse}

Korlederkompetanse omfatter en rekke elementer av svært ulik karakter, både musikalsk-teknisk og relasjonelt (Jansson, 2019). I forbindelse med lederrollen er kompetansebegrepet $i$ en viss forstand sirkulært - mestringstro er i seg selv en lederkompetanse (Paglis, 2010; Hannah et al., 2008; Huang, 2013). Det innebærer at dirigenter forholder seg til sin egen kompetanse i et samspill mellom faktiske ferdigheter og justering av egen praksis, slik at disse samlet sikrer mestring i rollen. Hva som er viktig er i stor grad et spørsmål om hva dirigenter tillater å være viktig. Selvforståelse er et handlende fenomen og er mer preget av pragmatisme enn det ideelle ( $\mathrm{Ng} \& \mathrm{Tan}$, 2009; Pye, 2005; Weick et al., 2005).

Vi har undersøkt den relative betydning av ulike kompetanseelementer på tre ulike plan: musikalsk-tekniske og relasjonelle-situasjonelle kompetanser i tillegg til eksistensielle forutsetninger (studie F). Et tydelig funn er at de eksistensielle faktorene, herunder vilje, autoritet, tilstedeværelse, hengivelse og oppriktighet rangeres først, mens musikalsk-tekniske kompetanser rangeres sist. Det er verdt å merke seg at denne vurderingen ikke varierer signifikant med ulike kontekstvariabler som utdannelse eller nivå på koret. Et tilsvarende mønster (basert på en liknende, men ikke identisk kompetansemodell) er også funnet for korps- og orkesterdirigenter i USA (Vallo, 2012). Det mest slående ved korlederes rangering av kompetansenes viktighet er at gestiske ferdigheter rangeres sist, samtidig som gestikk er det mest sentrale emnet i det meste av korlederutdanning. De musikalsk-tekniske ferdighetene som skiller seg fra hovedmønsteret er gehør og feilretting. Den mest nærliggende forklaringen er at dirigentfunksjonen er en lyttepost hvor gehør ikke kan erstattes med andre kompetanseelementer. Håndbevegelser og slagfigurer, derimot, kan i noen 
grad giøres mindre betydningsfulle i samspillet med andre kommunikasjonsformer som detaljerte verbalinstruksjoner, pianospill og blikk-kontakt.

Det korledere savner mest fra sine utdanninger er relasjonelle ferdigheter, som omfatter konkret veiledning og tilbakemelding så vel som håndtering av personkonflikter og sårbare korsangere (studie E, F og G). Nyutdannede korledere fra kortere programmer eller enkeltemner er ofte uforberedt på de mangfoldige menneskelige utfordringene i praksis (studie E). Dette er imidlertid ikke et tilsvarende problem for bachelor- og masterprogrammer som gir utviklingsmulighet over lengre tid, med både større fagbredde og -dybde. For de fleste korsangere er sangglede og fellesskap hovedmotivasjonen for å synge i kor (studie $\mathrm{A}$ og C). Korsang er lyden av fellesskap den har en særlig evne til å gi opplevelser av samhørighet (Balsnes, 2009, 2014). Innsikt i slike dimensjoner ved kordeltakelse vil prege dirigenters situasjons-relasjonelle kompetanse og deres eksistensielle grunnlag. For noen få dirigenter i vårt materiale er økonomi den viktigste begrunnelsen for å ta en dirigentjobb (studie G). Da er det desto viktigere å være klar over sangernes begrunnelser for å delta. For enkelte sangere kan koret være det viktigste sosiale knutepunktet, og deltakelsen helt avgjørende for å skape mening i tilværelsen (studie C). I tilfeller som Sang på jobben-kor kan sangerne tvert om være beordret til å delta for team-buildingens skyld (studie D). Uansett, å møte en dirigent som kun er opptatt av det musikalsk-tekniske, kan få store negative konsekvenser (Kreutz \& Brünger, 2012).

De to faktorene som mest forklarer variasjoner i selvopplevd kompetanse, er erfaring (antall år) og nivået på korene de dirigerer (studie F). Praksis dominerer over utdannelse, hvilket innebærer at justering av praksis gjøres på en slik måte at kompetanse stemmer med jobbsituasjonens utfordringer. Dette er nok et eksempel på organizational sensemaking (Weick, 1976, 1995, 1998), hvor tilpasningen skjer både konkret, for eksempel i valg av kor og repertoar, og ved forming av identitet, for eksempel ved å innse at man er en god nok dirigent for sitt lokalmiljø. En korleders livsløp er en vedvarende kompetanseutvikling, i et flettverk av ulike kor, kollegier og lokalsamfunn (studie G). En implikasjon er at det er begrenset hvor viktig utdanning er, på godt og vondt. Et alternativt syn er at utdanning i større grad burde ta et helhetsperspektiv på korlederpraksis og tilby større variasjon $i$ hva som undervises.

\section{Mangfold i dirigentenes profesjonelle livsløp}

Den store bredden i korvirksomhet - med hensyn til sjangere, aldre, ambisjonsnivå og sosial setting - preger også dirigentrollen, ikke minst fordi én og samme dirigent kan operere på ulike deler av feltet innenfor personens samlede praksis. Denne profesjonelle mangfoldigheten blir enda tydeligere når vi tar inn tidsperspektivet - korledelse er nemlig en praksis man står lenge i. For eksempel spenner yrkeserfaringen til norske dirigenter fra 1 til 65 år, og medianen er 22 år (studie F). Vi har i andre studier valgt å se dirigenters profesjonelle livsløp gjennom de fire kategoriene i Wengers (1998) teori om læring i praksisfellesskap: kompetanse, mening, fellesskap og identitet. De to første er karakterisert av et kumulativt forløp, i den forstand at kompetanse bygges 
kontinuerlig og det meningsfylte ved å være korleder forblir et eksistensielt prosjekt. De to siste er mer omskiftelige, både i form av konkret handling og med hensyn til selvoppfattelse. De er dermed også i særlig grad en kilde til variasjon og endring av karriereforløpet.

Korledere deltar i tre typer praksisfellesskap - korene de leder, lokalsamfunnene de virker i og fagfeller av ulike kategorier (studie G). Endringer i de to første skjer hver gang en dirigent bytter kor eller flytter på seg. Slike konkrete hendelser innebærer som oftest også en større eller mindre justering av identitet. Dirigenten som overtar et gospelkor uten tidligere erfaring med sjangeren, eller dirigenten som ikke får jobben han hadde ambisjoner om, gjennomgår ofte en brå tilpasning. En dirigentpraksis er dermed et eksempel på en vev av tilgrensende praksisfelleskap, hvor kompetanse og identiteter forhandles og omformes (Gherardi \& Nicolini, 2002; Oborn \& Dawson, 2010). Korledelse har preg av å være et kall, og personer med flere kall synes å være bedre beskyttet mot utilfredshet (Berg et al., 2010). Personer som deltar i flere praksisfelleskap har en større meny å forhandle med seg selv om. Våre studier viser at kun én av ti norske dirigenter er engasjert på fulltid, tre av ti er deltidsdirigenter og resten har korledelse som en marginal praksis i økonomisk forstand (studie F). Mange korledere har en blandet praksis, hvor både annen musikalsk og utenom-musikalsk virksomhet inngår (studie $\mathrm{G}$ ).

Vi har tidligere operasjonalisert korlederes identitet gjennom to variabler - transformasjon og intensitet (studie G). Transformasion handler om hvor fullstendig konverteringen til en dirigentidentitet er. For studenter på dirigeringsprogrammer av lengre varighet skjer gjerne transformasjon før eller tidlig i studiet. For dirigenter uten eller med kortere utdannelse skjer transformasjonen i praksis. Det finnes eksempler på øyeblikkelige oppvåkninger som dirigent, så vel som dirigenter som primært forblir sanger, organist, rockemusiker eller lærer, og hvor korledelse aldri blir mer enn et tilleggsverktøy.

Intensitet er ikke bare et spørsmål om hvor stor andel av årsverket som fylles av dirigentjobber, men denne andelen kan være én indikator. Hele spekteret finnes, fra ubetalte dirigenter til fulltidsdirigenten. Medianinntekten (som prosent av årsverket) er $20 \%$ i Norge, og $30 \%$ i Sverige (studie F). Selv i det begrensede utvalget av intervjuer av nylig eksaminerte studenter ved musikkhøyskolene i Skandinavia fant vi tilsvarende stor variasjon (studie E). Dirigentidentiteten kan fortsatt være sterk, selv når korledelse spiller en beskjeden rolle som andel av årsverk. Korledelse kan kompletteres av beslektede funksjoner som komponist/arranger, forsker, produsent og vokalpedagog - fortsatt innen rammen av en dirigentidentitet.

Til tross for at kjønn er eksplisitt synlig i kor via ulike stemmer og kortyper, er kjønn et lite framtredende tema i dirigentforskningen. En forklaring kan være at korledelse er en kjønnsmessig relativt godt blandet praksis. Gjennomsnittlig ligger andelen kvinner på $61 \%$; i Norge $66 \%$ og i Sverige $58 \%$ (studie F). I Norge er de mest framstående dirigentlærerne på høyskolenivå kvinner, mens det i Sverige er motsatt (studie E). Mannlige dirigenter vurderer sin selvopplevde kompetanse i noen grad 
lavere enn kvinner for kompetanseelementene mentorskap og autoritet (studie F). Menn opplever også at utdannelse har bidratt mindre til sitt nivå, og tilsvarende også når det gjelder kunstnerisk vilje og ledelse av innstudering. Dette er i noen grad konsistent med tidligere funn om forskjeller mellom kjønnene når det gjelder selvvurdering innen estetiske fag (mens det er motsatt for en del andre fag) (Beyer, 1990; Diseth et al., 2014; Huang, 2013; Ryckman \& Peckham, 1987). Hovedinntrykket er likevel at kor er en relativt balansert likestillingsarena, hvilket underbygger mangfoldighet i profesjonell praksis. Den viktigste implikasjonen av mangfoldigheten, er at overforenklede modeller av korledelse og standardiserte utdanningsopplegg risikerer å stemme dårlig med store deler av korfeltet.

\section{Avsluttende bemerkninger}

Formålet med den foreliggende artikkelen har vært å skissere en helhetlig konseptualisering for korlederkompetanse, -utdanning og -praksis. Ved hjelp av modellen har vi satt de ulike aspektene $i$ en dirigentkarriere i sammenheng med Janssons kompetansemodell og Wengers konsept om praksisfellesskap. Vi vil hevde at verdien ligger nettopp i selve sammensetningen. En svakhet ved konseptet læring i praksisfellesskap er at ved ensidig å se på hvordan læring foregår, uten å forholde seg til hva som skal læres, går vi glipp av kompetanseblikket. I konkrete læreprosesser må man også ha for øye hva som skal læres, og for korledelse tilføres det nettopp av kompetansemodellen.

Den helhetlige modellen knytter også sammen ulike faser i kordirigenters karrierer, fra et startpunkt som handler om rekruttering og inngangsprofil, via utdanning, som kan være mer eller mindre konstruktiv. Deretter følger en mangfoldig praksis hvor dirigentene fortsetter å utvikle seg, om det skjer via deltakelse i formelle videreutdannings- eller kurstilbud eller gjennom egen erfaring. Wengers konsept inneholder begrepet legitim perifer deltakelse. I denne teorien forstås læring som en dynamisk bevegelse fra perifer til full deltakelse i praksisfellesskapet. Det er ingen distinksjon mellom kjerne og periferi, alle deltakere har en legitim plass. Modellen kompletterer konseptet læring i praksisfellesskap ved å introdusere distinkte faser i kordirigenters livsløp.

Til sammen peker våre studier og analyser på flere utfordringer for utdanningsinstitusjonene: Hvordan kan de utstyre studentene med en variert verktøykasse kombinert med en beredskap eller refleksivitet i møte med praksisfeltets utfordringer? Hva skal prioriteres i undervisningen? Det artistiske eller pedagogiske? Enkeltemner eller øvetid med ensemble? Ulike kortyper eller fokus på en type ensemble, for eksempel profesjonelle kor? Og hvordan kan relasjonelle aspekter ivaretas i undervisningen? Er det mulig å legge mer (reell) praksis inn i utdanningen? De samme spørsmålene kan stilles til kurstilbudet som kororganisasjonene organiserer. Uansett, en korleders utdanning er et livslangt prosjekt som foregår i flere ulike praksisfellesskap hvor kompetanse, identitet og mening er sammenvevd. Formell utdanning er bare en av flere veier. Å få et best mulig samsvar mellom utdanning og praksis er 
avgjørende. Samtidig er det elementer i en dirigents kompetanse som kun kan læres gjennom levd liv, slik en nyutdannet dirigent formulerer det i forbindelse med studie $\mathrm{E}:$ «Vi må lære på veien uansett, men vi er godt forberedt.»

\section{Forfatterbiografier}

Dag Jansson er førsteamanuensis i kulturledelse ved Handelshøyskolen, OsloMet og universitetslektor i korledelse ved Högskolan för Scen och Musik i Gøteborg. Hans forskningsområde er estetikk og ledelse, hvor en nøkkelpublikasjon er monografien Leading Musically, utgitt på Routledge (2018). Andre sentrale publikasjoner er på feltet dirigentkompetanse, blant disse «Choral conductor competences: Perceptions and priorities» (2019) og «Universality and situatedness in educating choral conductors» (2019). Han har blant annet skrevet et kapittel om korsangeres opplevelse av musikalsk lederskap i The Oxford Handbook of Singing. Jansson er også aktiv kordirigent.

Anne Haugland Balsnes er professor i musikk ved Universitetet i Agder. Hun har publisert innen musikkpedagogikk, community music og musikk og helse-feltet, med særlig fokus på korsang, -ledelse og -utdanning. Blant hennes publikasjoner finnes «Singing for a Better Life. Choral Singing and Public Health» i antologien Music and Public Health: A Nordic Perspective utgitt på Springer (2018), og, sammen med Dag Jansson, "Choral conducting education: The life-long entanglement of competence, identity, and meaning» i Research Studies in Music Education (2019). Balsnes er også utøvende sanger og kordirigent.

\section{Referanser}

Adler, S. (1985). Choral conducting: An anthology (2. utg.). Schirmer Books.

Apfelstadt, H. (2009). Woman conductors as leaders and mentors. I J. C. Conlon (Red.), Wisdom, wit and will. Woman choral conductors on their art (s. 157-82). GIA Publications.

Armstrong, S. \& Armstrong, S. (1996). The conductor as transformational leader. Music Educators fournal, $82(6), 22-5$.

Arthur, L. (2016). Communities of practice in higher education: professional learning in an academic career. International fournal for Academic Development, 21(3), 230-41. https://doi.org/10.1080/1360144X.2015. 1127813

Atik, Y. (1994). The conductor and the orchestra: Interactive aspects of the leadership process. Leadership and Organization Development fournal, 15(1), 22.

Balsnes, A. H. (2009). A lare $i$ kor: Belcanto som praksisfellesskap (NMH-publikasjoner 2009:7). Norges musikkhøgskole.

Balsnes, A. H. (2014a). A synge $i$ kor - ideal for menneskelig fellesskap. Portal forlag.

Balsnes, A. H. (2014b). I get sick when I don't go to choir practice. Choral Singing as a Health Promoting Resource. I U. Geisler \& K. Johansson (Red.), Choral Singing: Histories and Practices. (s. 232-249). Cambridge Scholars Publishers.

Balsnes, A. H. \& Jansson, D. (2015). Unfreezing Identities: Exploring choral singing in the workplace. International fournal of Community Music, 8(2), 163-178.

Balsnes, A. H. (2016). Hospitality in multicultural choral singing. International fournal of Community Music, 9(2), 171-189.

Balsnes, A. H. (2017). The Silver Voices: A possible model for senior singing. International fournal of Community Music, 10(1), 59-69. 


\section{Korlederens kompetanse, utdanning og praksis}

Balsnes, A. H. (2018). Singing for a better life. Choral singing and public health. I L. O. Bonde \& T. Theorell (Red.), Music and Public Health: A Nordic Perspective. (s. 167-186). Springer.

Bandura, A. (1977). Self-efficacy: Toward a unifying theory of behavioral change. Psychological Review 84(2), 191-215. https://doi.org/10.1037/0033-295X.84.2.191

Bass, B. M. \& Steidlmeier, P. (1999). Ethics, character, and authentic transformational leadership behavior. The Leadership Quarterly, 10(2), 181-217. http://dx.doi.org/10.1016/S1048-9843(99)00016-8

Bathurst, R. \& Cain, T. (2013). Embodied leadership: The aesthetics of gesture. Leadership, 9(3), 358-77. https://doi.org/10.1177/1742715013485851

Beck, C. D., Gerhardt, M., \& Peluchette, J. V. (2014). Antecedents of servant leadership: A mixed methods study. Fournal of Leadership and Organizational Studies, 21(3), 299-314. https://doi.org/10.1177/154805181 4529993

Berg, J., Grant, A. \& Johnson, V. (2010). When callings are calling: Crafting work and leisure in pursuit of unanswered occupational callings. Organization Science, 21(5), 973-94. https://doi.org/10.1287/orsc. 1090.0497

Beyer, S. (1990). Gender differences in the accuracy of self-evaluations of performance. Fournal of Personality and Social Psychology 59(5), 960-70. https://doi.org/10.1037/0022-3514.59.5.960

Biasutti, M. (2013). Orchestra rehearsal strategies: Conductor and performer views. Musicae Scientiae, 17(1), 57-71. https://doi.org/10.1177/1029864912467634

Bjørndal, B. \& Lieberg, S. (1978). Nye veier i didaktikken. Aschehoug.

Black, M. (2014). «Bouncing and dancing»: The use and effect of verbal imagery in choral directing. I U. Geisler \& K. Johansson, Choral singing. Histories and practices. (s. 208-231). Cambridge Scholars Publishing.

Blocker, R. (2004). The Robert Shaw Reader. Yale University Press.

Bonshor, M. J. 2017). Conductor feedback and the amateur singer: The role of criticism and praise in building choral confidence. Research Studies in Music Education, 39(2), 139-60. https://doi.org/10.1177/1321103x 17709630

Brunner, D. L. (1996). Carefully crafting the choral rehearsal. Music Educators fournal, 83(3), 37-9.

Burger, B., Thompson M. R., Luck G., Saarikallio S. H. \& Toiviainen, P. (2014). Hunting for the beat in the body: On period and phase locking in music-induced movement. Frontiers in Human Neuroscience, 8(903). https://doi.org/10.3389/fnhum.2014.00903

Butt, J. (2010). Choral conducting: A mythology in practice. Fournal of the Royal Musical Association, 135(2), 419-23. https://doi.org/10.1080/02690403.2010.506278

Bygdéus, P. (2015). Medierande verktyg $i$ körledarpraktik — en studie av arbetssätt och handling $i$ körledning med barn och unga [Doktorgradsavhandling]. Lund Universitet.

Byo, J. L. (1990). Recognition of intensity contrasts in the gestures of beginning conductors. Fournal of Research in Music Education, 38(3), 157-63. https://doi.org/10.2307/3345179

Campion, M. A., Cheraskin, L. \& Stevens, M. J. (1994). Career-related antecedents and outcomes of job rotation. Academy of Management fournal, 37(6), 1518.

Campion, M. A., Fink, A. A., Ruggeberg, B. J., Carr, L., Phillips, G. M. \& Odman, R. B. (2011). Doing competencies well: Best practices in competency modeling. Personnel Psychology, 64(1), 225-265.

Cofer, R. S. (1998). Effects of conducting-gesture instruction on seventh-grade band students' performance response to conducting emblems. Fournal of Research in Music, Education 46(3), 360-73.

Coutinho, E. (2010). Cognitive dissonance, knowledge instinct and musical emotions. Physics of Life Reviews, 7(1), 30-2. https://doi.org/10.1016/j.plrev.2009.12.005

Cox, J. (1989). Rehearsal organizational structures used by successful high school choral directors fournal of Research in Music Education, 37(3), 201-18. https://doi.org/10.2307/3344670

Crowe, D. R. (1996). Effects of score study style on beginning conductors' error-detection abilities. Fournal of Research in Music Education, 44(2), 160-71. https://doi.org/10.2307/3345668

Diseth, A., Meland, E. \& Breidablik, H.-J. (2014). Self-beliefs among students: Grade level and gender differences in self-esteem, self-efficacy and implicit theories of intelligence. Learning and Individual Differences, 35, 1-8. https://doi.org/10.1016/j.lindif.2014.06.003

Durrant, C. (1994). Towards a model of effective communication: a case for structured teaching of conducting. British fournal of Music Education, 15(1), 40-9.

Durrant, C. (2000). Making choral rehearsing seductive: Implications for practice and choral education. Research Studies in Music Education, 15(1), 40-9. https://doi.org/10.1177/1321103x0001500106

Durrant, C. (2003). Choral conducting: Philosophy and practice. Routledge. 


\section{Fansson og A. H. Balsnes}

Durrant, C. \& Varvarigou, M. (2008). Real time and virtual: tracking the professional development and reflections of choral conductors. Reflecting Education, 4(1), 72-80.

Eiksund, Ø. J. (2019). Koret som spenningsfelt. Mellom det små og det store (NMH-publikasjoner 2019:1). Norges musikkhøgskole.

Faulkner, R. R. (1973). Orchestra interaction: Some features of communication and authority in an artistic organization. Sociological Quarterly, 14(2), 147-57. https://doi.org/10.1111/j.1533-8525.1973.tb00850.x

Festinger, L. (1957). A theory of cognitive dissonance. Stanford University Press.

Fisher, K. \& Robbins, C. R. (2015). Embodied leadership: Moving from leader competencies to leaderful practices. Leadership, 11(3), 281-99. https://doi.org/10.1177/1742715014522680.

Fowler, C. \& Swan, H. (1987). Conscience of a profession: Howard Swan, choral director and teacher. Hinshaw Music.

Freer, P. K. (2011). The performance-pedagogy paradox in choral music teaching. Philosophy of Music Education Review, 19(2), 164-78. https://doi.org/10.2979/philmusieducrevi.19.2.164

Fuelberth, R. J.V. (2003). The effect of left hand conducting gesture on inappropriate vocal tension in individual singers. Bulletin of the Council for Research in Music Education, (157), 62-70.

Gardner, W. L., Cogliser, C. C., Davis, K. M. \& Dickens, M. P. (2011). Authentic leadership: A review of the literature and research agenda. The Leadership Quarterly, 22(6), 1120-45. http://dx.doi.org/10.1016/ j.leaqua.2011.09.007

Garnett, L. (2009). Choral conducting and the construction of meaning: gesture, voice, identity. Ashgate Publishing.

Geisler, U. (2010). Choral research. A global bibliography. Körcentrum Syd.

Geisler, U. \& Johansson, K. (2014). Choral singing: Histories and practices. Cambridge Scholars Publishing.

Gherardi, S., Nicolini, D. \& Odella, F. (2000). Towards a social understanding of how people learn in organizations: the notion of the situated curriculum. Fournal of Managerial Psychology, 713.

Gherardi, S. \& Nicolini, D. (2002). Learning in a constellation of interconnected practices: Canon or dissonance? Fournal of Management Studies, 39(4), 419-36. https;//doi.org/10.1111/1467-6486.t01-1-00298

Gilling, D. (2014). From Mahler to the movies: physical empathy in orchestral leadership. I D. Ladkin \& S. S. Taylor (Red.), The physicality of leadership: gesture, entanglement, taboo, possibilities. (s. 109-133). Emerald Group Publishing.

Gonzo, C. (1973). Research in choral music: a perspective. Bulletin of the Council for Research in Music Education 33, 21-33.

Grant, J. W. \& Norris, C. (1998). «Choral music education: A survey of research 1982-1995.» Bulletin of the Council for Research in Music Education 135 (winter): 21-59.

Guise, P. E. (2001). Director or leader? How to gain control of the choir (and how to give it away). I A. Rose \& K. Adams (Red.), Sharing the voices: the phenomenon of singing III. (s. 132-7). Memorial University of Newfoundland.

Gumm, A. J. (2018). Music conducting functions: A mixed-methods evaluation of theory and survey validity. Psychomusicology, 28(4), 189-200. https://doi.org/10.1037/pmu0000218

Gumm, A. J. (2012). Six functions of conducting. Music Educators fournal, 99(2), 43-9. https://doi.org/10.1177/ 0027432112458705

Handley, K., Sturdy, A., Fincham, R. \& Clark, T. (2006). Within and beyond communities of practice: Making sense of learning through participation, identity and practice. Fournal of Management Studies, 43(3), 641-53. https://doi.org/10.1111/j.1467-6486.2006.00605.x

Hanken, I. M. \& Johansen, G. (2013). Musikkundervisningens didaktikk. Cappelen Damm Akademisk.

Hannah, S. T., Avolio, B. J., Luthans, F. \& Harms, P. D. (2008). Leadership efficacy: Review and future directions. The Leadership Quarterly, 19(6), 669-92. https://doi.org/10.1016/j.leaqua.2008.09.007

Hinojosa, A. S., Gardner, W. L., Walker, H. J., Cogliser, C. \& Gullifor, D. (2017). A review of Cognitive dissonance theory in management research: Opportunities for further development. Fournal of Management, 43(1), 170-99. https://doi.org/10.1177/0149206316668236

Huang, C. (2013). Gender differences in academic self-efficacy: a meta-analysis. A fournal of Education and Development, 28(1), 1-35. https://doi.org/10.1007/s10212-011-0097-y

Humphreys, M., Ucbasaran, D. \& Lockett, A. (2012). Sensemaking and sensegiving stories of jazz leadership. Human Relations, 65(1), 41-62. https://doi.org/10.1177/0018726711424320

Hylton, J. (1983). A survey of choral education research. Bulletin of the Council for Research in Music Education, 76(Fall), 1-29.

Jansson, D. (2013). Musical leadership: the choral conductor as sensemaker and liberator (NMH-publikasjoner 2013:4). Norges musikkhøgskole. 


\section{Korlederens kompetanse, utdanning og praksis}

Jansson, D. (2018). Leading musically. Routledge.

Jansson, D. (2019). Choral singers' perceptions of musical leadership. I G. Welch, D. Howard \& J. Nix (Red.), The Oxford handbook of singing (s. 865-85). Oxford University Press.

Jansson, D. \& Balsnes, A. H. (2015). Unfreezing identities: Exploring choral singing in the workplace. International fournal of Community Music, 8(2), 163-178.

Jansson, D., Balsnes, A. H. (2020). Choral conducting education: The life-long entanglement of competence, identity, and meaning. Research Studies in Music Education, 1(18), 1-19.

Jansson, D., Balsnes, A. H. \& Bygdéus, P. (2018). Nordic choral conductor education: Overview and research agenda. Nordic Research in Music Education Yearbook 2018, (19), 137-70.

Jansson, D., Elstad, B. \& Døving, E. (2019a). Choral conducting competences: Perceptions and priorities. Research Studies in Music Education, 1-19. https://doi.org/10.1177/1321103X19843191

Jansson, D., Elstad, B. \& Døving, E. (2019b).Universality and situatedness in educating choral conductors. Music Education Research, 21(4), 344-58. https://doi.org/10.1080/14613808.2019.1626362

Johansson, K. (2015). A cappella. Tjugofem körledares röster. Bo Ejeby Förlag.

Kreuz, G. \& Brünger, P. (2012). A shade of grey: Negative associations with amateur choral singing. Arts $\mathcal{G}$ health, 4(3), 230-238.

Ladkin, D. (2008). Leading beautifully: How mastery, congruence and purpose create the aesthetic of embodied leadership practice. The Leadership Quarterly, 19(1), 31-41.

Ladkin, D. \& Taylor, S. S. (2010). Enacting the 'true self': Towards a theory of embodied authentic leadership. The Leadership Quarterly, 21(1), 64-74. http://dx.doi.org/10.1016/j.leaqua.2009.10.005

Lave, J. (2012). Changing practice. Mind, Culture, and Activity, 192(2), 156-71. https://doi.org/10.1080/10749 039.2012 .666317

Lave, J. \& Wenger, E. (1991). Situated learning: legitimate peripheral participation. Cambridge University Press.

Luck, G. \& Toiviainen, P. (2006). Ensemble musicians' synchronization with conductors' gestures: An automated feature-extraction analysis. Music Perception, 24(2), 189-200. https://doi.org/10.1525/mp.2006.24.2.189

Luck, G \& Nte, S. (2008). An investigation of conductors' temporal gestures and conductor-musician synchronization, and a first experiment. Psychology of Music, 36(1), 81-99. https://doi.org/10.1177/0305 735607080832

Luck, G. \& Sloboda, J. (2008). Exploring the spatio-temporal properties of simple conducting gestures using a synchronization task. Music Perception: An Interdisciplinary fournal, 25(3), 225-39. https://doi.org/10.1525/ mp.2008.25.3.225

Morrison, S. J., Price, H. E., Smedley, E. M., Meals, C. D. \& Morrison, S. J. (2014). Conductor gestures influence evaluations of ensemble performance. Frontiers in Psychology, 5(806), 1-8. https://doi.org/10.3389/fpsyg. 2014.00806

Napoles, J. (2013). The influences of presentation modes and conducting gestures on the perceptions of expressive choral performance of high school musicians attending a summer choral camp. International Fournal of Music Education, 31(3), 321-30. https://doi.org/10.1177/0255761411434823

Napoles, J. (2014). Verbal instructions and conducting gestures: Examining two modes of communication. Fournal of Music Teacher Education, 23(2), 9-20. https://doi.org/10.1177/1057083712474936

$\mathrm{Ng}$, P. T. \& Tan, C. (2009). Community of practice for teachers: sensemaking or critical reflective learning? Reflective Practice, 10(1), 37-44. https://doi.org/10.1080/14623940802652730

Oborn, E. \& Dawson, S. (2010). Learning across communities of practice: An examination of multidisciplinary work: Learning across communities of practice. British fournal of Management, 21(4), 843-58. https://doi. $\operatorname{org} / 10.1111 / j .1467-8551.2009 .00684 . x$

Paglis, L. L. (2010). Leadership self-efficacy: research findings and practical applications. Fournal of Management Development, 29(9), 771-82. https://doi.org/10.1108/02621711011072487

Patman, B. A. (1987). Defining power and its uses for the choral conductor. Choral journal, 28(4), 21-6.

Pye, A. (2005). Leadership and organizing: Sensemaking in action. Leadership, 1(1), 31-49. https://doi. org/10.1177/1742715005049349

Raelin, J. A. (2020). Toward a methodology for studying leadership-as-practice. Leadership, 16(4), 480-508. https://doi.org/10.1177/1742715019882831

Rennie, D. L. (2012). Qualitative research as methodical hermeneutics. Psychological Methods, 17(3), 385-98. https://doi.org/10.1037/a0029250

Ryckman, D. B. \& Peckham, P. (1987). Gender differences in attributions for success and failure situations across subject areas. The fournal of Educational Research, 81(2), 120-5. https://doi.org/10.1080/00220671.1987. 10885808 


\section{Fansson og A. H. Balsnes}

Sandberg-Jurström, R. (2009). Att ge form åt musikaliska gestaltningar: en socialse- miotisk studie av körledares multimodala kommunikation $i$ kör [Doktorgradsavhandling]. Göteborgs Universitet.

Silvey, B. A. (2013). The role of conductor facial expression in students' evaluation of ensemble expressivity. Fournal of Research in Music Education, 60(4), 419-29. https://doi.org/10.1177/0022429412462580

Skadsem, J. A. (1997) ). Effect of conductor verbalization, dynamic markings, conductor gesture, and choir dynamic level on singers' dynamic responses. Fournal of Research in Music Education, 45(4), 509-20. https:// doi.org/10.2307/3345419

Stambaugh, L. A. (2016. Differences in error detection skills by band and choral preservice teachers. Fournal of Music Teacher Education, 25(2), 25-36. https://doi.org/10.1177/1057083714558421

Timmermans, S. \& Iddo, T. (2012). Theory construction in qualitative research: from grounded theory to abductive analysis. Sociological Theory, 30(3), 167-86. https://doi.org/10.1177/0735275112457914

Vallo, V. (1990). Conducting and music education: a review of selected research. Update:Applications of Research in Music Education, 9(1), 13-6.

Vallo, V. (2012). The traits of a successful conductor-educator. School Band and Orchestra, 15(5), 26-30.

Van Weelden, K. (2002). Relationships between perceptions of conducting effectiveness and ensemble performance. Fournal of Research in Music Education, 50(2), 165-76. https://doi.org/10.2307/3345820

Van Weelden, K. \& McGee, I. R. (2007). The influence of music style and conductor race on perceptions of ensemble and conductor performance. International fournal of Music Education, 25(1), 7-17. https://doi. org/10.1177/0255761407074886

Varvarigou, M. \& Durrant, C. (2011). Theoretical perspectives on the education of choral conductors: A suggested framework. British fournal of Music Education, 28(3), 325-38. https://doi.org/10.1017/ S0265051711000325

Weick, K. E. (1976). Educational organizations as loosely coupled systems. Administrative Science Quarterly, 21(1), 1-19. https;//doi.org/10.2307/2391875

Weick, K. E. (1995). Sensemaking in organizations, Foundations for organizational science. Sage.

Weick, K. E. (1998). Improvisation as a mindset for organizational analysis. Organization Science, 9(5), 543-55.

Weick, K. E., Sutcliffe, K. M. \& Obstfeld, D. (2005). Organizing and the process of sensemaking. Organization Science, 16(4), 409-21. https://doi.org/10.1287/orsc.1050.0133

Wenger, E. (1998). Communities of practice. Learning, meaning and identities. Cambridge University Press.

Wis, R. M. (2002). The conductor as servant-leader. Music Educators fournal, 89(2), 17-23.

Woodbury, W. (1955). Leadership in orchestral conducting. Fournal of Research in Music Education, 3(2), 119-30. https;//doi.org/10.2307/3343626

Wöllner, C. (2008). Which part of the conductor's body conveys most expressive information? A spatial occlusion approach. Musicae Scientiae, 12(2), 249-72. https://doi.org/10.1177/102986490801200204

Yarbrough, C. (1975). Effect of magnitude of conductor behavior on students in selected mixed choruses. fournal of Research in Music Education, 23(2), 134-46. https://doi.org/10.2307/3345286

Yarbrough, C. \& Madsen, K. (1998). The evaluation of teaching in choral rehearsals. Fournal of Research in Music Education, 46(4), 469-81. https;//doi.org/10.2307/3345344

Yoo, H. (2017). Multicultural choral music pedagogy based on the facets model. Music Educators fournal, 104(1), 34-9. https;//doi.org/10.1177/0027432117708602 